\title{
Editorial on the special issue "Coping with Local Challenges of Population Decline and Ageing - Case Studies from Germany"
}

\author{
Paul Gans, Claus Schlömer
}

For some years, demographic change with its effects on Germany's future population development has been an important subject in socio-political discussions as, for instance, the Federal Government's Demographic Strategy documents. Although Germany's population rose in 2013, as it did in the two previous years, this increase to 80.8 million inhabitants at the end of 2013 resulted from a net migration gain of over 400,000 people from abroad, more than balancing out the negative difference of births and deaths of about 210,000 people in these years. Since, at an average of 1.4 births per woman, fertility in Germany has been one-third below the natural reproduction level for approximately 40 years, the deficit of births will continue to grow in future. The consequences are declining population figures and a relative and absolute increase in older people alongside a continuous loss in significance of younger age groups. Temporarily, immigration gains can quantitatively and qualitatively attenuate this trend, but they cannot reverse it in the long term.

This development raises questions on societal challenges, and sustainable solutions to these challenges are crucial for preserving the quality of life in Germany. What kind of effects on economic development are to be expected from the decline in population figures? What kind of influence does the ageing of the population have on funding our social security systems? To what extent does the declining number of young people of working age endanger our economy's global competitiveness? Can active immigration policies diminish the lack of younger workers? Can local authorities handle the challenges of integrating people with immigration backgrounds, challenges that increase along with immigration? What kind of impacts does the rise in single-person households have on social structures? With regard to public services, what consequences does the population decline in rural regions have on the quality of life of the people living there?

These dimensions of demographic change have inherent regional characteristics, i.e. there are considerable deviations between regions with both comparable and different settlement structures and sizes with regard to population development and structure. Figure 1 illustrates the contrast in population development in eastern and western Germany for the period of 1990 until 2010. The causes lie in the distinctive decline in fertility in eastern Germany until 1994 as well as in the out-migration of many people to western Germany. In the early 1990s, in western Germany there was an additional population increase as a consequence of immigra- 
tion gains, mainly from formerly socialist states. Figure 1 also emphasizes regional differences that are expressed in the opposing trend of population development between prospering and economically weak regions. In eastern Germany, this contrast is closely linked to an urban-rural gradient, as "landmarks" like Berlin, Dresden and Leipzig indicate; while in western Germany the regional differentiation of population development only reflects settlement structures to a certain extent, it is, rather, influenced by economic disparities. For example, both agglomerations and rural regions recorded growing (e.g. Munich, Rhine-Main, foothills of the Alps, northwestern Germany) as well as declining population figures (e.g. Ruhr, Saarland, parts of Upper Franconia, Hesse and southeastern Lower Saxony). For Germany as a whole, we observe an intraregional redistribution of the population in the period of 1990 until 2010. In particular couples with children move from the urban districts to their surrounding areas to improve their housing situation. Suburbanisation began in western Germany in the 1950s and has continued, with varying intensity, until today. In eastern Germany, by contrast, it does not become significant for settlement development until the mid-1990s, supported by tax reduction for private residential property.

Nevertheless, since the year 2000 there have been increasing signs of changing spatial patterns of internal migration, which Nikola Sander examines in the first article of the special issue. She analyses the spatial structure and dynamics of internal migrations in 397 districts in Germany between 1995 and 2010. With regard to the geographical consequences of demographic change for population distribution and structure, two results are striking. The intensity of migration from eastern to western Germany has continuously lessened since 2001, lying distinctly below the frequency of migrations between the sub-regions within eastern Germany in 2010. Patterns form in favour of the growth of Berlin, Dresden, Leipzig, Potsdam, Jena and Erfurt, where positive economic effects are observed in relatively relaxed urban housing markets. She also identifies this re-urbanisation trend in western Germany. This concentration process is led by young adults who prefer to live in bigger cities for educational and job-oriented reasons. These internal migration flows are selective both with regard to age structure and geography, with the losses occurring in more rural and peripheral regions. By contrast, districts with institutes of higher education and a wide variety of educational opportunities profit from the influx of 18 to under 25-year-olds, and core cities in agglomerations with a knowledge-based economic structure as well as diversified jobs have great appeal for 25 to under 30-year-olds. At the same time, urban development projects are revitalising brownfields and changes in the working environment are increasing the appeal of living in the city rather than the suburbs, with the consequence that the outflow of classic suburbanites from cities with housing markets that are not over-strained is declining.

According to population projections by the Federal Institute for Research on Building, Urban Affairs and Spatial Development, in the period from 2010 until 2030 development will be characterised by a slow tilting from growth to shrinkage (Fig. 2). From a spatial perspective, this trend corresponds to growing and shrinking regions existing side by side with a more or less continuously lessening number of growing 
Fig. 1: Population development in Germany by districts (1990-2010)

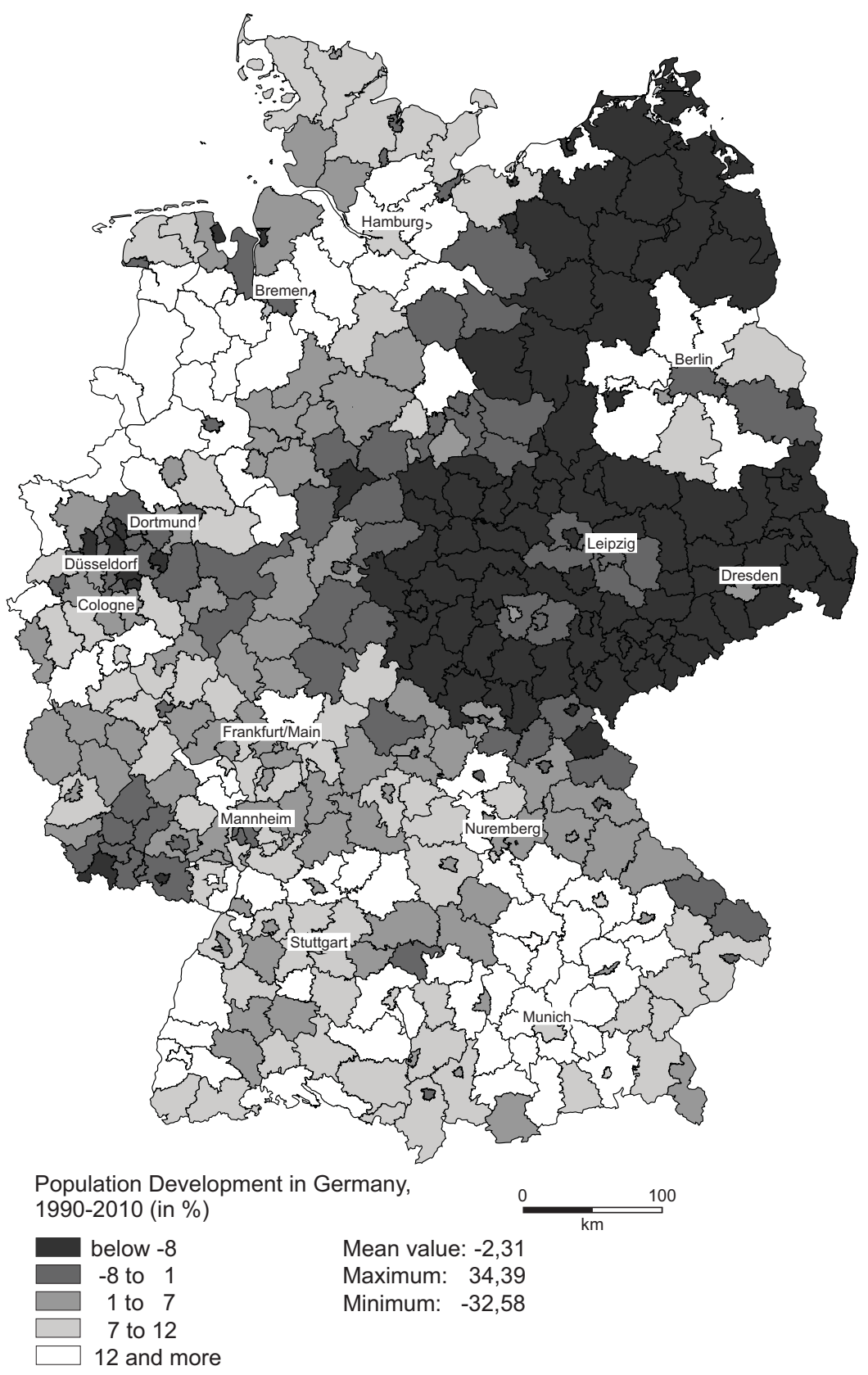

Source: Own design based on data from the Regional Development Projection by the Federal Institute for Research on Building, Urban Affairs and Spatial Development (BBSR) 
Fig. 2: Population development in Germany by districts (2010-2030)

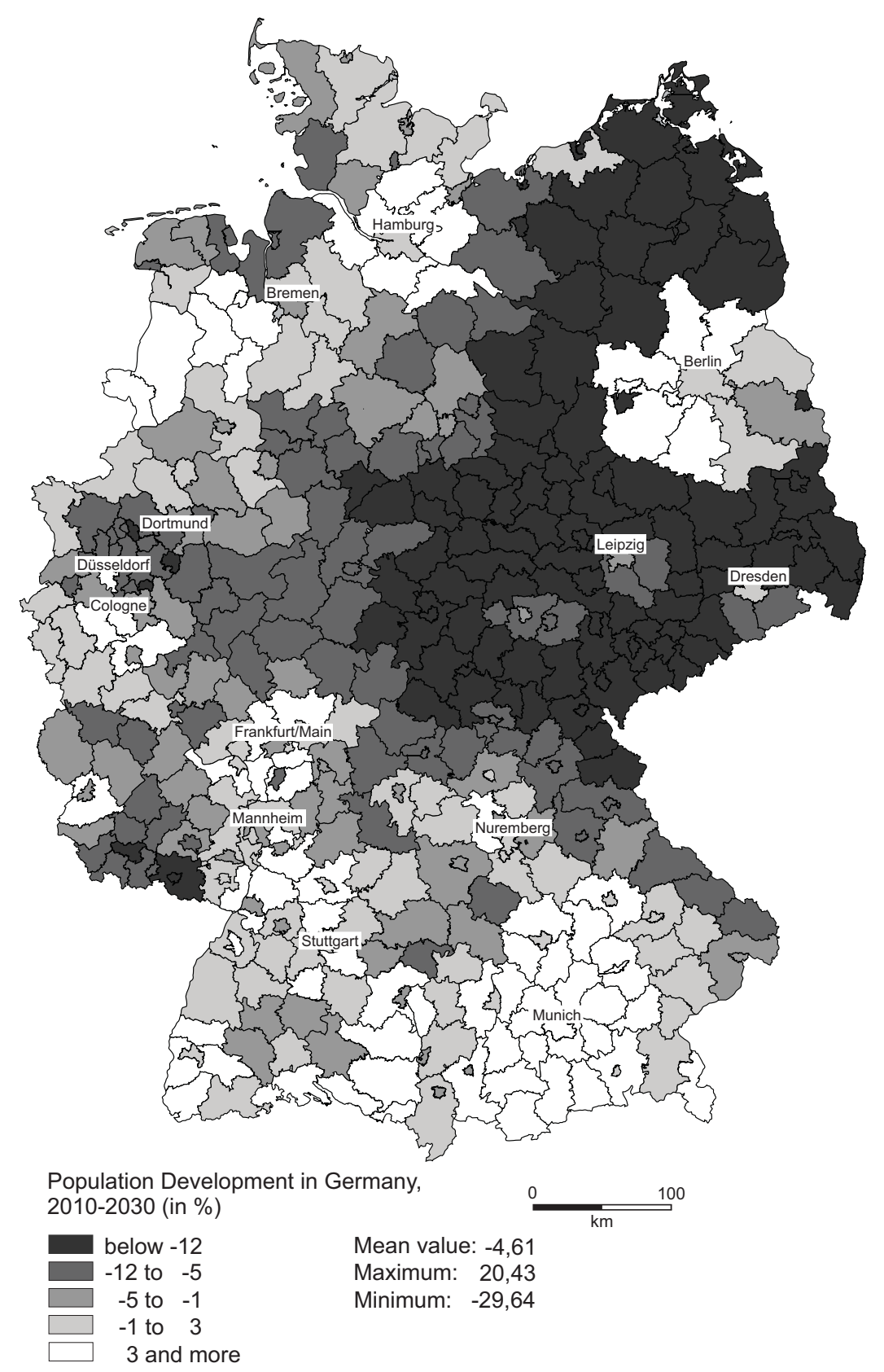

Source: Own design based on data from the Regional Development Projection by the Federal Institute for Research on Building, Urban Affairs and Spatial Development (BBSR) 
sub-regions. While in the 1990s, the decline in the population concentrated mainly on eastern Germany, in future more and more regions will have declining population figures in the west as well. Hence, the former inner-German border has ceased to exist, as depicted in Figure 2. Instead, a wedge-shape appears from northern Hesse and the southern part of Lower Saxony that reaches to the Ruhr, in which shrinking areas realign to ever larger areas. By contrast, the remaining growing regions in the south and northwest increasingly look like islands. This process has accelerated in the recent past and will continue in future. Within eastern Germany, around Berlin and - less pronounced - in Leipzig, Dresden and the series of towns in the Thuringian Basin, "islands of stability" stand out from large shrinking regions, which are predominantly rural.

While in the longer run population dynamics tend to reflect patterns that largely agree with economic opposites and regional disparities, the ageing of the population, particularly in terms of aspects regarding the settlement structure, reveals unique characteristics, even if the basic features of regions with advanced ageing largely match those with shrinking as do regions with below average ageing of the population and growth (Figs. 1, 3, 4). This dichotomy, which is mainly based on different numbers of women of childbearing age, is, however, overlaid by small-scale yet highly systematic opposites. For example, most large cities with a rise in the average age of their inhabitants of 2.5 years (2010-2030) display a comparatively steady age structure, since both external and internal migrations lead to population gains among young adults and to losses among older inhabitants. The shifts of the age-structure outside the large cities are all the greater. The increase of older people in the direct surroundings of large cities, where the average age of the population is rising by about four years in western and by five years in eastern Germany, is particularly prominent. In the west, this development is a "long-term consequence" of earlier age-selective, pronounced city-to-hinterland migrations.

Over the course of the suburbanisation process that began in the 1950s, singlefamily home neighbourhoods were built, some of them quite large, in which resident ageing has progressed greatly due to the owners' immobility. As a consequence of this "ageing in place", in coming years we expect that a large share of housing stocks will be put up for sale during the change of generations. In their article, Zakrezewski, Berndgen-Kaiser, Fox-Kämper and Siedentop deal with the situation of single-family home neighbourhoods built in the 1950s, '60s and '70s. Based on extensive case studies in five western German states, they demonstrate how the interaction of neighbourhood characteristics (e.g. image, location), the housing stocks and thus the housing supply (e.g. construction, energy shortcomings) as well as demand (e.g. change in household structures and residential needs, rise or drop in owneroccupier age groups) lead to different types of developments. Single-family home neighbourhoods that are fast sells or anticipating "filtering up" (a rise in social status of the households due to selective influx) may require (if at all) stabilising measures by local authorities. But in neighbourhoods anticipating "filtering down", in which the change of generations is accompanied by increasing vacancies, modernisation backlogs and diminished images, municipal interventions are needed that aim to increase quality and restructure in order to counteract a future downward spiral of the 
Fig. 3: Average age of the population in Germany by districts (2010)

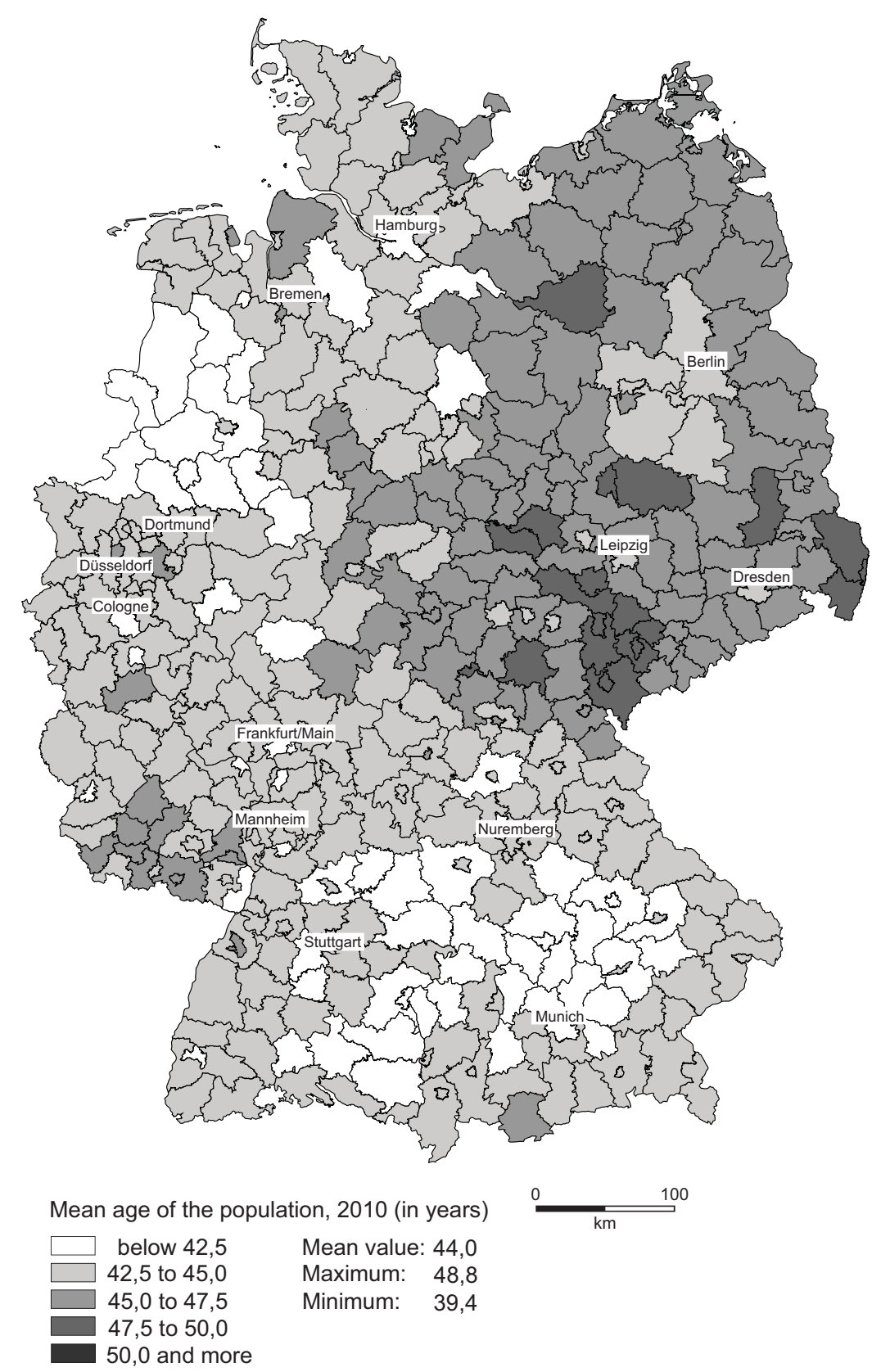

Source: Own design based on data from the Federal Institute for Research on Building, Urban Affairs and Spatial Development (BBSR) 
Fig. 4: Average age of the population in Germany by districts (2030)

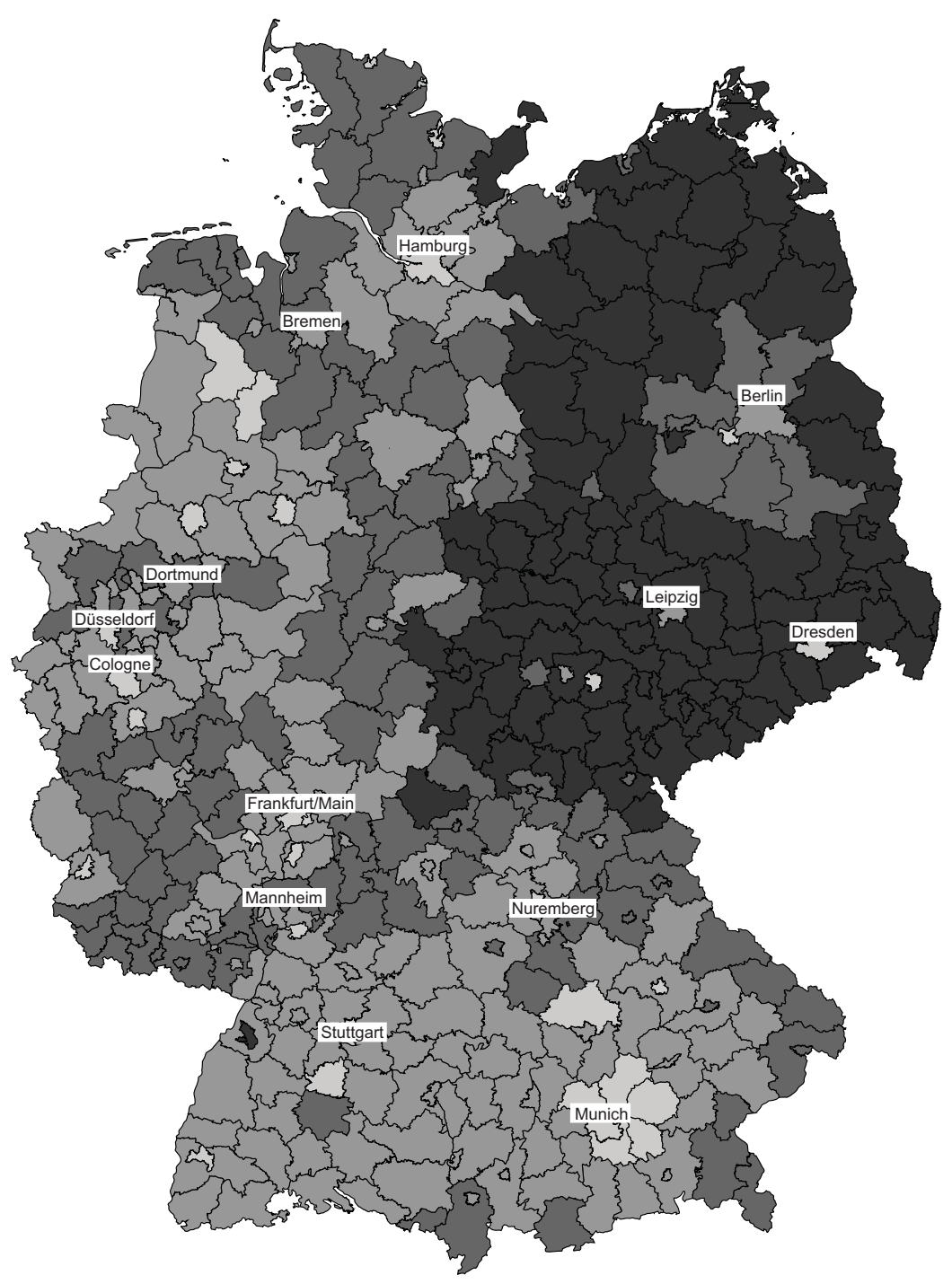

Mean age of the population, 2030 (in years)

below 42,5

42,5 to 45,0

45,0 to 47,5

47,5 to 50,0

50,0 and more
Mean value: 47,9

Maximum: $\quad 55,6$

Minimum: $\quad 43,3$

Source: Own design based on data from the Federal Institute for Research on Building, Urban Affairs and Spatial Development (BBSR) 
residential areas. The authors provide recommendations for such actions derived from interviews with real estate experts and municipal representatives.

In both eastern and western Germany a second source of ageing, namely the decrease of young people, rather affects rural regions than agglomerations. In western Germany in particular this is a relatively new development. In eastern Germany the decline in numbers of young people was already more pronounced in GDR times than in the West. Consequently, demographic ageing is particularly pronounced in places where a decline in numbers of younger people is accompanied by an increase in numbers of older people. This describes almost all of eastern Germany outside of big cities and increasingly also sub-regions in the west.

The article by Steinführer, Küpper and Tautz focuses on how public services are safeguarded in regions with low population density using the example of a rural region straddling the former border in the Harz area. The region is affected by a population decline and very progressed population ageing due to years of selective out-migration of young adults and influx of older people. The associated challenges are discussed on the basis of semi-structured interviews with key regional individuals and group interviews with elderly inhabitants of two towns in the Harz area from two perspectives: the adaptive strategies of stakeholders who need to provide public services and the coping strategies of the older population reacting to the changing supply. The many options for maintaining and shaping public services aim at lowering their density and centralisation in favour of larger municipalities. Their implementation is increasingly limited by economic and human resources. Older people pursue active strategies to cope with their daily lives, however their available social capital is limited by increased age accompanied by less dense social networks and health restrictions limit personal resources. The article also reveals that problem-solving strategies are rather of short-term nature.

Educational institutions are very important for rural regions. Their existence ensures residential appeal for families, thus counteracting population decline and ageing. Educational institutions also cast a positive light on other public services. Bart/ uses the example of Saxony-Anhalt to discuss strategies pursuing the objective of adapting the different levels of the educational system (pre-school to university) to changing demands. Between 1991 and 2012 Saxony-Anhalt recorded a decline in population of almost 20 percent, and almost 60 percent among under 18-year-olds. The state's financial straits require an adaptive strategy that exhausts all saving potentials, however there are a variety of reasons that oppose this objective such as institutional differences between educational levels, changes in demand behaviours, for example for childcare, and the trend towards higher educational degrees, but also the welfare state objective of ensuring equal access to all levels of the educational system in all sub-regions of the states and the influence of municipalities on the preservation of educational facilities aimed at securing the residential appeal of the respective town. Generally, reduced costs in education must be balanced out, for example with increasing costs for public budgets in other sectors or with negative welfare state consequences for educational quality.

The articles examine the challenges resulting from the spatial divergence of population development and ageing. In shrinking regions this leads to vacancies and 
losses in value on real estate markets and in growing regions to housing shortages and excessive price increases. Quantitative and qualitative changes in demand have led to both the enhancement and reduction of public services including technical infrastructures for communication, water supply and disposal, social infrastructures in the educational and health systems, local public transport, public safety and local amenities. The articles discuss adaptation and coping strategies, options for actions by private households as well as representatives of various administrative levels using the examples of public services, education and housing.

Prof. Dr. Paul Gans ( $₫$ ). University of Mannheim, Chair of Economic Geography, Mannheim, Germany. E-Mail: paulgans@uni-mannheim.de URL: http://gans.vwl.uni-mannheim.de/1461.1.html

Dr. Claus Schlömer. Bundesinstitut für Bau-, Stadt- und Raumforschung (BBSR) im Bundesamt für Bauwesen und Raumordnung (BBR), Referat I 1 "Raumentwicklung", Bonn, Germany. E-Mail: claus.schloemer@bbr.bund.de URL: http://www.bbsr.bund.de 


\section{Comparative Population Studies}

WWW.comparativepopulationstudies.de

ISSN: 1869-8980 (Print) - 1869-8999 (Internet)

Published by / Herausgegeben von

Prof. Dr. Norbert F. Schneider

Federal Institute for Population Research

D-65180 Wiesbaden / Germany

Managing Editor /

Verantwortlicher Redakteur

Frank Swiaczny

Assistant Managing Editor /

Stellvertretende Redakteurin

Katrin Schiefer

Language \& Copy Editor (English) /

Lektorat \& Übersetzungen (englisch)

Amelie Franke

Copy Editor (German) /

Lektorat (deutsch)

Dr. Evelyn Grünheid

\section{Layout / Satz}

Beatriz Feiler-Fuchs

E-mail:cpos@bib.bund.de

\author{
Scientific Advisory Board / \\ Wissenschaftlicher Beirat \\ Paul Gans (Mannheim) \\ Johannes Huinink (Bremen) \\ Michaela Kreyenfeld (Rostock) \\ Marc Luy (Wien) \\ Clara H. Mulder (Groningen) \\ Notburga Ott (Bochum) \\ Peter Preisendörfer (Mainz) \\ Zsolt Spéder (Budapest)
}

\section{Board of Reviewers / Gutachterbeirat} Martin Abraham (Erlangen)

Laura Bernardi (Lausanne)

Hansjörg Bucher (Bonn)

Claudia Diehl (Konstanz)

Andreas Diekmann (Zürich)

Gabriele Doblhammer-Reiter (Rostock)

E.-Jürgen Flöthmann (Bielefeld)

Alexia Fürnkranz-Prskawetz (Wien)

Beat Fux (Salzburg)

Joshua Goldstein (Berkeley)

Karsten Hank (Köln)

Sonja Haug (Regensburg)

Aart C. Liefbroer (Den Haag)

Kurt Lüscher (Konstanz)

Dimiter Philipov (Wien)

Tomáš Sobotka (Wien)

Heike Trappe (Rostock) 